\title{
Proximate composition, functional properties and quantitative analysis of benzoyl peroxide and benzoic acid in wheat flour samples: effect on wheat flour quality
}

\author{
Numrah Nisar ${ }^{1}$, Faiza Mustafa ${ }^{1}$, Arifa Tahir ${ }^{1}$, Rashad Waseem Khan Qadri ${ }^{\text {Corresp., }}{ }^{2}$, Yaodong Yang ${ }^{3}$, Muhammad \\ Imran Khan ${ }^{4}$, Fuyou Wang ${ }^{3}$ \\ ${ }^{1}$ Department of Environmental Sciences, Lahore College for Women University, Lahore, Punjab, Pakistan \\ 2 Institute of Horticultural Sciences, University of Agriculture Faisalabad, Faisalabad, Punjab, Pakistan \\ 3 Hainan Key Laboratory of Tropical Oil Crops Biology/Coconut Research Institute, Chinese Academy of Tropical Agricultural Science, Wenchang, Hainan, \\ China \\ 4 Institute of Soil and Environmental Sciences, University of Agriculture Faisalabad, Faislabad, Punjab, Pakistan \\ Corresponding Author: Rashad Waseem Khan Qadri \\ Email address: rashad.qadri@uaf.edu.pk
}

Background. Extensive milling processes have deprived wheat flour from essential nutrients. The objective of the current study was to assess the nutritive quality of commercial wheat flour (soft flour/SF) through analyses of proximate composition and functional properties as well as quantification of benzoyl peroxide (BPO; added as bleaching agent in the SF) by comparing the results with whole wheat flour (WF; never received any additives). Methods. The samples included commercial soft flour (SF) purchased from the local supplier of different flour mills (who use BPO as additive) and a control sample without additives was prepared by grinding the seeds harvested from wheat (Triticum aestivum L.; Inqulab 91) crop grown in the experimental field of University of Agriculture, Faisalabad, under optimized field conditions without any fertilizers and insecticides. Functional properties (including bulk density, water absorption capacity, oil absorption capacity, emulsifying activity, foaming capacity, least gelatinization concentration and gelatinization temperature) and proximate composition (including moisture content, ash contents, crude protein, gluten and starch contents) were determined and compared for all the samples. Benzoyl peroxide (BPO) and Benzoic Acid (BA) quantification was performed through High Performance Liquid Chromatography (HPLC). Finally dietary intake was estimated for BPO and BA. Results. Results showed that SF had lesser fiber, protein and ash contents, whereas, higher damaged starch, fat, gluten and bulk density. A parallel experiment under selected conditions (temperature, time and solute concentration) showed dissociation of BPO into BA soon after the exposure. Observed BA range (13.77 mg/g after 16h) in SF and exposure level assessment $(44.3 \pm 1.36 \mathrm{mg} / \mathrm{kg} / \mathrm{BW})$ showed higher intake of BA on the consumption of SF. Results 
revealed superiority of WF over SF in nutritive qualities as well as free of toxicants such as BA. 


\section{Proximate composition, functional properties and}

2 quantitative analysis of benzoyl peroxide and benzoic

3 acid in wheat flour samples: effect on wheat flour quality

4

5 Numrah Nisar ${ }^{1}$, Faiza Mustafa ${ }^{1}$, Arifa Tahir ${ }^{1}$, Rashad Qadri ${ }^{2 *}$, Yaodong Yang $^{3}$, Muhammad

6 Imran $\mathrm{Khan}^{4}$, Fuyou Wang ${ }^{3}$

7

$8{ }^{1}$ Department of Environmental Sciences, Lahore College for Women University, Lahore, Punjab,

9 Pakistan

${ }^{2}$ Institute of Horticultural Science, University of Agriculture Faisalabad, Faisalabad, Punjab,

11 Pakistan

$12{ }^{3}$ Hainan Key Laboratory of Tropical Oil Crops Biology/Coconuts Research Institute, Chinese

Academy of Tropical Agricultural Sciences, Wenchang, Hainan, China

$14{ }^{4}$ Institute of Soil and Environmental Sciences, University of Agriculture Faisalabad, Faisalabad,

15 Punjab, Pakistan

Corresponding Author:

18 Rashad Qadri²

${ }^{2}$ Institute of Horticultural Science, University of Agriculture, Faisalabad, Faisalabad, Punjab,

20 Pakistan

21 Email address: rashad.qadri@uaf.edu.pk

22 


\section{Abstract}

30 Background.

31 Extensive milling processes have deprived wheat flour from essential nutrients. The objective of 32 the current study was to assess the nutritive quality of commercial wheat flour (soft flour/SF)

33 through analyses of proximate composition and functional properties as well as quantification of 34 benzoyl peroxide (BPO; added as bleaching agent in the SF) by comparing the results with whole 35 wheat flour (WF; never received any additives).

\section{Methods.}

The samples included commercial soft flour (SF) purchased from the local supplier of different flour mills (who use BPO as additive) and a control sample without additives was prepared by grinding the seeds harvested from wheat (Triticum aestivum L.; Inqulab 91) crop grown in the experimental field of University of Agriculture, Faisalabad, under optimized field conditions without any fertilizers and insecticides. Functional properties (including bulk density, water absorption capacity, oil absorption capacity, emulsifying activity, foaming capacity, least gelatinization concentration and gelatinization temperature) and proximate composition (including moisture content, ash contents, crude protein, gluten and starch contents) were determined and compared for all the samples. Benzoyl peroxide (BPO) and Benzoic Acid (BA) quantification was performed through High Performance Liquid Chromatography (HPLC). Finally dietary intake was estimated for BPO and BA.

\section{Results.}

Results showed that SF had lesser fiber, protein and ash contents, whereas, higher damaged starch, fat, gluten and bulk density. A parallel experiment under selected conditions (temperature, time and solute concentration) showed dissociation of BPO into BA soon after the exposure. Observed $\mathrm{BA}$ range $(13.77 \mathrm{mg} / \mathrm{g}$ after $16 \mathrm{~h})$ in $\mathrm{SF}$ and exposure level assessment $(44.3 \pm 1.36 \mathrm{mg} / \mathrm{kg} / \mathrm{BW})$ showed higher intake of BA on the consumption of SF. Results revealed superiority of WF over $\mathrm{SF}$ in nutritive qualities as well as free of toxicants such as BA.

KEYWORDS: Benzoyl peroxide; Benzoic acid; Soft Flour; Whole Wheat Flour; High Performance Liquid Chromatography 


\section{Introduction}

59 Wheat (Triticum aestivum L.) is a principal cereal consumed world-wide in different forms, as a

60

61

62

63

64

65

66

67

68

69

70

71

72

73

74

75

76

77

78

79

80

81

82

83

84

85

86

87 major food source. During milling process the grains are milled to obtain flour which is pale yellow in colour. The bakery products it yields are less commercially acceptable, therefore flour is bleached for different bakery items. When this flour is stored, natural maturation or aging takes place, where carotenoids undergo oxidation and improves rheological properties of the dough such as texture (Liu et al. 2014). Lutein (a xanthophyll) is excessively found in the wheat seeds $(\approx 3 \mathrm{mg} / \mathrm{kg}$ of dried wheat) and the yellow colour of the bread is due to the remains of lutein in - - wheat seeds (Mellado-Ortega \& Hornero-Méndez 2017).

Wheat milling industries utilize oxidizing agents such as benzoyl peroxide (BPO) to accelerate the process of maturation and dough improvement. These agents oxidize sulf-hydryl groups in flour gluten protein that yields increased stickiness of the flour and makes its appearance as soft flour (SF) (Onishi et al. 2004b). These oxidizing agents can be used for bleaching and dough improvement. During flour bleaching conjugated double bond of carotenoids is disrupted to less conjugated colorless system, which gives flour a desirable texture for baking. One of the most commonly used oxidizing agent is BPO which exhibits bleaching properties without influencing the baking or taste (Gaddipati et al. 1983). BPO is a free radical initiator and it produces carotenoid oxidation like a typical free radical mechanism. No acceptable limits of BPO have been specified in the food safety regulations. BPO has been extensively used throughout the world as a bleaching agent without any recovery. In food processing BPO is ( $>92 \%)$ converted into benzoic acid (BA), which is usually used as a preservative for soft drinks, fruits, juices and many other types of food items. The higher concentration of BA than allowable safety level (40 mg/kg) is harmful for humans. Acute toxicity is unknown, however, a sensitive person consuming BA more than $5 \mathrm{mg} / \mathrm{kg}$ of body weight (BW) per day can initiate non-immunological (pseudo-allergy) reactions, hyperpnoea, metabolic acidosis and convulsions (Wei et al. 2006; Liu 2007).

Beside addition of BPO, the SF is processed several times compared to the WF to achieve the fiber free fine particles for the improved texture of the bakery products. During this processing structure, sensory qualities, protein contents, fiber contents and nutritional components get severely affected. Antioxidants in WF, which are present in the germ and bran (Isabelle \& Andre 2006), are mostly removed in the refined flour. Therefore, the current study was designed to observe and compare the proximate composition and functional properties of SF and WF as well as BPO and BA 
89 concentrations in them. Current study also considered the conversion of BPO to BA at different 90 time intervals after adding a known concentration of BPO to WF (control; without additives; 91 grown under similar conditions to control with additives). The findings will help to identify the 92 levels of BA in SF which may get consumed and nutritional deprivation as a result of intensive 93 grinding and sieving of wheat flour during milling.

\section{Materials \& Methods}

95 Sample collection

96 Test samples included commercial soft flour $(n=4, S F)$ purchased from the local supplier from 97 different flour mills (with additives) and a control sample ( $\mathrm{n}=1$, WF) without additives was 98 prepared by mechanical grinding the Triticum aestivum L. seeds (Inqulab 19), harvested from the 99 crop grown on the experimental field of University of Agriculture, Faisalabad, under optimized field conditions $\left(16 / 8 \mathrm{D} / \mathrm{N} ; 23 \pm 1^{\circ} \mathrm{C} ; 14\right.$ Inch water) without any fertilizer and insecticide. The variety of wheat seeds and growth conditions were kept same as used by flour mills to generate $\mathrm{SF}$, to avoid ambiguity in results. The WF flour sample was passed through sieve ( $75 \mu \mathrm{m}$ size) before packing them into air-tight plastic containers. The size was in agreement with the particle size of SF purchased from flour mills.

105

106

107

108

109

110

111

112

113

114

115 116

\section{Determination of functional properties}

Bulk density of flour was determined as described previously (Jehu-Appiah et al. 2011) by following ASTM D1895B prescribed procedure. The sample was allowed to flow freely in a circular container $(0.615 \mathrm{~L})$ with a suspended funnel of opening diameter $(1.5 \mathrm{~cm})$. The height of funnel was kept about $20 \mathrm{~cm}$ and the powder was stirred continuously to avoid clogging inside the opening. Container with the sample was dropped few times from the height of $150 \mathrm{~mm}$ to allow settling and release of air. Weight of the container with the sample was determined and weight/volume (loose bulk density) was obtained. Density was determined through the formula, $d=\frac{m}{v}$, where mass $(g)$ is the weight of the sample and volume $(\mathrm{mL})$ is the volume of the material. Water absorption capacity and oil absorption capacity (WAC and OAC respectively) were determined through the method described by Beuchat (1977). In this method, 1g of sample was allowed to mix with $10 \mathrm{~mL}$ of distilled water for about $30 \mathrm{sec}$. Sample was then allowed to stand 
117 at room temperature $\left(25 \pm 2{ }^{\circ} \mathrm{C}\right)$ for the next $30 \mathrm{~min}$ and centrifuged at $3000 \mathrm{rpm}(30 \mathrm{~min})$. Volume 118 of the supernatant was determined and WAC $(\mathrm{mg} / \mathrm{mL})$ was calculated by formula $W A C=V_{\text {initial }}$ $119-V_{\text {final }}$, where $\mathrm{V}$ is the volume of water $(\mathrm{mL})$. Similar procedure was repeated for OAC 120 determination using soybean oil (Sp. Gravity 0.9092) as the absorbing agent. Emulsifying stability 121 and emulsifying activity (ES and EA respectively) were determined by the method described by 122 Neto et al. (2001) with modifications. About $5 \mathrm{~mL}$ of flour dispersion $(10 \mathrm{mg} / \mathrm{mL}$ of water) was 123 homogenized with $5 \mathrm{~mL}$ of soybean oil for $1 \mathrm{~min}$ through vigorous shaking. The emulsion was 124 then centrifuged (Sigma 2-6, Germany) at $1100 \mathrm{rpm}$ for $10 \mathrm{~min}$. Height $(\mathrm{cm})$ of emulsified layer 125 (ELH) was deducted from the total height of the tube contents (TC) to estimate the EA by the 126 equation $E A=\left(\frac{E L H}{T C}\right) \times 100$. ES was calculated by heating the emulsion at $80^{\circ} \mathrm{C}$ for 30 min before 127 centrifuging at $1300 \mathrm{rpm}$ for $10 \mathrm{~min}$. ES was then calculated by $E S=\left(\frac{E L H A}{T C A}\right) \times 100$, where ELHA 128 is the height of emulsified layer after heating and TCA is total content of the tube before heating. 129 The effect of EA and ES was determined by varying the capacity of the flour samples. Foaming 130 stability and capacity (FS and FC) of flours were determined by the method reported by Coffmann 131 \& Garciaj (1977), where about $100 \mathrm{~mL}$ of distilled water was mixed with $10 \mathrm{~g}$ of flour. The 132 suspension was mixed vigorously for $5 \mathrm{~min}$ on the magnetic stirrer (Irmco MSC Digital, 133 Germany). The initial solution volume $V_{1}$ and the final solution volume $V_{2}$ were recorded (using 134 graduated cylinder). Foaming Capacity (FC) was also calculated from the formula $F C=\left(\frac{V_{2}-V_{1}}{V_{1}}\right.$ 135 ) $\times 100$. Foaming Stability (FS) was also determined by the foam volume that was left for $8 \mathrm{~h}$ and 136 expressed as percentage of initial foam volume. To determine the gelation properties; Least gelatinization concentration (LGC) and gelatinization temperature (GnT), distilled water sample suspensions $(2-10 \% \mathrm{w} / \mathrm{v})$ were prepared. About $10 \mathrm{~mL}$ of these suspensions were transferred into the test tubes. In the boiling water bath these test tubes were heated for $1 \mathrm{~h}$ and then cooled for $2 \mathrm{~h}$ at $4{ }^{\circ} \mathrm{C}$ in a refrigerator. Least gelation concentrations were taken when the samples did not fall 141 from the inverted test tubes.

\section{Proximate composition}

143 Proximate composition was determined through FT-NIR spectroscopy (Burker-TENSOR 37 FTIR 144 spectrometer, Germany) as well as conventional methods to get reliable results. These properties 145 included moisture content (MC), ash contents (AC), crude protein (CP), gluten and starch contents. 
146 Other properties such as crude fiber and fat (CFF) were determined through solvent extractions. 147 For crude fiber about 2.5-3g of sample was transferred to Soxhlet and extracted with petroleum 148 ether. The air dried extracted sample was transferred to $1 \mathrm{~L}$ conical flask. Whole boiling dilute 149 sulphuric acid $(1.25 \% \mathrm{w} / \mathrm{v})$ was transferred to the flask containing sample and immediately 150 connected with a water cooled reflux condenser and heat it so that the contents start boiling in 1 151 min. Few drops of octanol were added to avoid bumping and risk of foaming. The flask was 152 continuously shaken and boiled for 30min. Flask is then removed and filtered through fine linen 153 (18 threads to a cm) placed in a funnel and washed with boiling water until no longer acid to litmus 154 is achieved. The residue on linen was then washed with the $200 \mathrm{~mL}$ of boiling $\mathrm{NaOH}(1.25 \% \mathrm{w} / \mathrm{v})$. 155 Immediately the flask was connected to the reflux condenser and boiled for $30 \mathrm{~min}$. The residue 156 was then filtered through filtering cloth and residues were thoroughly washed with boiling water. 157 The residues were transferred to Gooch crucible having thin compact layer of ignited asbestos. 158 Finally wash the residues with $15 \mathrm{~mL}$ ethyl alcohol. The Gooch crucible was dried in air oven at $159105 \pm 2{ }^{\circ} \mathrm{C}$ in an air oven until constant weight is achieved. The crucible was weighed and placed in 160 a muffle furnace to burnt all carbonaceous matter. Crucible was then cooled and weighed again.

161 Crude fiber was then calculated by the following formula; crude fiber $\%$ by $w t=\frac{\left(W_{1}-W_{2}\right) \times 100}{W}$, 162 where $\mathrm{W}_{1}$ is weight of Gooch crucible before ashing, $\mathrm{W}_{2}$ is weight of Gooch Crucible containing 163 asbestos and ash and $\mathrm{W}$ is weight of the dried material taken for the test. The fat content of wheat 164 was determined using the method of Association of Official Analytical chemists (AOAC, 2000) 165 with petroleum ether as solvent. In this method the fat was extracted by petroleum ether. Sample 166 of about $3.0 \mathrm{~g}$ was weighed and added in a labelled thimble. About $150 \mathrm{~mL}$ of petroleum ether was 167 then added to it and boiled upto $40-60^{\circ} \mathrm{C}$ in $250 \mathrm{~mL}$ boiling flask. The thimble was tightly plugged 168 with cotton wool and Soxhlet apparatus was assembled to allow it to reflux for $24 \mathrm{~h}$ the thimble 169 was carefully removed and petroleum ether from the top was drained into another container for further use. The petroleum ether was then evaporated completely in a hot air oven and desiccator 171 was weighed following cooling. The weight was determined by formula; fat content $\%$ by wt = $172 \frac{W_{1} \times 100}{W}$, where $W_{1}$ is the weight of the residue in desiccator and $\mathrm{W}$ is initial weight of the sample. 173 Since the bulk density $(\mathrm{BD} ; \rho)$ varies with $\mathrm{MC}$, therefore, it was determined following procedure 174 described in ASABE standard S358.2 (Theerarattananoon et al. 2011). During this procedure, 100 $175 \mathrm{~g}$ of sample was dried in a forced air convection oven (IM-115, Germany) at $103{ }^{\circ} \mathrm{C}$ for $24 \mathrm{~h}$. The 
176 sample was then weighed on digital balance (0.01 g precision; TE-313S-DS, Germany) and MC 177 was calculated by the equation; $M C=W_{\text {initial }}-W_{\text {final }} . \mathrm{MC}$ was also determined through FT-NIR 178 spectroscopy. Flour samples of different moisture level were utilized to develop the model for 179 calibration and multivariate analysis was conducted after gathering their spectra. Unknown 180 samples were then analyzed against the calibration curve to get the moisture contents. Crude 181 protein was determined through semi micro-Kjeldahl method (AACC adopted method 46-13; 182 American association for cereal chemistry, 1995) and auto protein analyzer (Kjeltec 2400 auto183 analyzer, Hillerod, Denmark). Here $1 \mathrm{~g}$ of flour sample was used along with keeping nitrogen to 184 protein conversion factor of 5.7. AACC method 38-12 was utilized to determine the gluten 185 contents of the selected flour samples (25 g each).

186

187

188

189

190

191

192

193

194

195

196

197

198

199

200

201 202

\section{Analytical method}

NIR Omega G Analyser (Bruins Instruments, USA) was employed to analyze different parameters (protein, starch, fat, moisture, gluten) of the flour and grain samples. The spectral transmissions range was 700-1100 nm with $5 \mathrm{~nm}$ scan increment, measured at controlled room conditions of $24 \pm 1^{\circ} \mathrm{C}, \mathrm{RH} 34 \pm 2 \%$.

\section{MIR spectroscopy}

The FTIR transmission spectra were recorded at Burker-TENSOR 37 FTIR spectrometer with Michelson interferometer. Working range of the spectrometer was 4000-12000 $\mathrm{cm}^{-1}$ and spectra generated were interpreted on the basis overtones of different functional groups in the product. Resolution of spectrometer was $4 \mathrm{~cm}^{-1}$ (max scan interval value was $\left.2 \mathrm{~cm}^{-1}\right)$ with maximum scan time kept at 5 sec. MIR spectra were recorded at Opus 6.0 Burker Software using Attenuated Total Reflectance (ATR) unit. The reference spectrum (empty sample bottle) was utilized as background measurement before loading in sample's spectra. About 8-10 g of sample was added in the sample bottle to generate the spectra in diffused reflectance mode. Three spectra per sample were recorded by rotating the sample bottle at $120^{\circ}$. The measurements were carried out under the controlled conditions of temperature $24 \pm 1^{\circ} \mathrm{C}, \mathrm{RH} 34 \pm 2 \%$. Each spectra were the average of 3 scans per object. 


\section{BP and BA quantification}

204 Sample preparation and bleaching reaction

205 BPO and BA were quantified in wheat flour as described by the method of Abe-Onishi et al., 2004.

206 Whole wheat sample was taken and divided into two parts; one sample was kept as control and

207 BPO was added in the other. About $50 \mathrm{~g}$ of flour was blended with $1.5 \mathrm{mg}$ of BPO (bleaching agent)

208 to achieve a concentration of $30 \mu \mathrm{g} / \mathrm{g}$. The mixture was passed through polyester sieve (400

$209 \mathrm{mesh} / \mathrm{cm}^{2}$ ) to attain the homogeneous blend and kept in dark. The bleaching reaction (performed

210 at room temperature) was monitored after every hour. The product of reaction was extracted every

211 hour for a period of $8 \mathrm{~h}$, finally a sample was taken at $12 \mathrm{~h}$ and $16 \mathrm{~h}$. Then samples were analysed

212 by HPLC and compared with the commercial standards and calibration graph for the

213 quantification. Associated peaks (matching with the standard) were considered for the generation 214 of results.

\section{Calibration Graph for BPO}

216 Standard stock solution (SS) was generated by dissolving pure BPO $(60 \mathrm{mg} / \mathrm{L})$ in diethyl ether

217 (100\% purity). Working standards were obtained by diluting SS with appropriate volume of diethyl 218 ether. For BA stock solution, pure compound $(100 \mathrm{mg})$ was dissolved in $100 \mathrm{~mL}$ of methanol and 219 working standards were prepared by diluting the stock solution. Calibration curve was then 220 generated by plotting the absorbance value against concentration.

\section{Extraction Procedure for BPO and BA.}

222 The standard procedure was carried out (at room temperature) in a flask with grinding stopper.

223 About $100 \mathrm{~mL}$ of diethyl ether was added to $50 \mathrm{~g}$ of flour (both control and the one which is already 224 mixed and sifted with BPO). This mixture was shaken vigorously on a magnetic stirrer for 10 225 minutes and left to settle for 15 minutes. Upper layer of this solution (containing the products of 226 reaction) was withdrawn through the pipette and transferred into Falcon polypropylene tube $227(10 \mathrm{~mL})$ and held into ice until HPLC analysis.

\section{HPLC method}

229 The supernatant was analyzed by Waters 600 HPLC system at Inertsil ODS-80A column $(5 \mu \mathrm{m}$, 2304.6 × $250 \mathrm{~mm}$; GL science Tokoyo, Japan) equipped Inertsil ODS-3 guard column $(10 \mathrm{~mm} \times 4 \mathrm{~mm}$ 
231 i.d.) and Waters 2996 Photodiode array detector. The detection wavelength was kept at $235 \mathrm{~nm}$ and 232 column oven at $40^{\circ} \mathrm{C}$. For isocratic separation the conditions were as follows: Water (Solvent A), 233 acetonitrile (CAN; solvent B) and Benzoic acid (Solvent C); 55\% B:45\%A as mobile phase for $2341 \mathrm{~mL} / \mathrm{min}$. The gradient conditions for analysis were as follows: Water-glacial acetic acid (1000:1) 235 (Solvent A), ACN-glacial acetic acid (1000:1) (solvent B); 18\% B (10 min) was increased to 60\% $236 \mathrm{~B}\left(11-15 \mathrm{~min}\right.$ hold) at flow rate $1.2 \mathrm{~mL} / \mathrm{min}$ and column temperature $35^{\circ} \mathrm{C}$.

\section{Estimation of dietary intake}

238 The mean dietary intake for both BP and BA were estimated to determine the exposure rate. For 239 this purpose, 200 subjects (35-40 years of age group; random sampling) were evaluated for their 240 preferences of WF and SF as well as amount of daily intake through a questionnaire survey. The 241 SF brands, which were reported to be consumed, were actually evaluated for the presence of BA 242 in the current study. Further calculations were accomplished through the following equation:

$$
Y=\sum\left(X_{v} \times C_{v}\right) / B_{w}
$$

244 Where; $\mathrm{X}_{\mathrm{V}}=$ average daily amount $(\mathrm{kg})$ of wheat flour consumed by a subject

$245 \mathrm{C}_{\mathrm{v}}=$ concentration of BA $(\mathrm{mg} / \mathrm{kg})$ as determined through HPLC in particular wheat flour sample $246 \mathrm{~B}_{\mathrm{w}}=$ Average body weight of the subject

\section{Statistical analysis}

248 All samples were analyzed in triplicate (both biological and experimental replicates), therefore 249 standard error of mean (SEM) was applied using the Statistixl 1.9 Add-in package within Excel 250 2007. Two-way analysis of variance (ANOVA) was conducted, followed by post-hoc Tukey tests 251 that separated the treatment into groups (at $P<0.01$ and $P<0.05$ ). The aim was to give the 252 significant difference in the data sets from different flour samples which was not achievable 253 through univariate or one-way ANOVA.

\section{Results}

255 Both the commercially available soft flour (SF) and whole wheat flour (WF) were compared for 256 their functional properties, emulsifying properties, foaming capacity, gelation capacity, proximate 257 composition and benzoyl peroxide composition. Finally, the exposure of benzoyl peroxide was compared with the daily intake capacity to observe the exposure of consumers when they are 
259 consuming SF or WF. The samples of SF were collected from the flour mills which were preferably 260 consumed by the subjects. WF samples were collected from same seed variety (Inqulab 19) grown 261 under similar conditions as wheat of SF. Detailed results are as under.

\section{Functional Properties}

263 The oil absorption capacity (OAC; Table 1) showed that the SF sample has highest lipophilic 264 tendency of about $2.87 \mathrm{~mL} / \mathrm{g}$. Highest OAC (188 mL/100g compared to $146 \mathrm{~mL} / 100 \mathrm{~g}$ for $\mathrm{WF})$ 265 and WAC ( $408 \mathrm{~g} / 100 \mathrm{~mL}$ compared to $140 \mathrm{~g} / 100 \mathrm{~mL}$ for WF) were obtained for SF4. All considered 266 flour mill samples had almost similar results for OAC. Water Absorption Capacity (WAC) was, 267 however, higher $(140 \mathrm{~g} / 100 \mathrm{~mL})$ for WF compared to SF $(<123 \mathrm{~g} / 100 \mathrm{~mL})$.

268 The results revealed that emulsifying Activity (EA) was higher for WF (43.7\%), whereas, stability 269 (ES) is higher for all SF samples $(<42 \%)$. EA and ES of the WF and SF may also vary due to the 270 milling process. The emulsifying properties varied inversely, which means that WF had highest 271 EA and lowest ES. Foaming Capacity (FC) and Foaming stability (FS) collectively form the 272 foaming properties of any flour. Both of these properties are directly proportional to one another, 273 which were observed to be higher for WF (12.9\% FC and 1.94\% FS). FC and FS of WF is more $274(<12 \%$ and $<1 \%$ respectively) compared to all SF samples ( $>9 \%$ and $>1 \%$ respectively). A highly 275 significant difference $(P<0.01)$ was observed when values were compared statistically with those 276 of WF.

\section{Gelation capacity}

278 Gelation capacity (including gelatinization temperature GnT and least Gelatinization 279 concentration LGC) are attributed and controlled by the balance between hydrophilic interactions 280 and repulsive electrostatic interactions between the water/oil and proteins (Casanova et al. 2008). 281 Results (Table 1) indicated that WF had higher gelation capacity $\left(\mathrm{GnT}=59.21^{\circ} \mathrm{C}\right.$; $\mathrm{LGC}=8 \%$ ) 282 compared to all SF samples ( $P<0.001$ when datasets were compared with the WF dataset). It can 283 also be observed that both considered parameters for gelation capacity are directly related to each 284 other such that increase in one also showed increase in the other.

285

286 287

\section{Proximate composition}

The proximate composition (moisture, crude fiber, fat, ash, starch, damaged starch) of all the flour samples is as summarized in the Table 2. Moisture content of SF is less (3.84-4.25\%), protein 
288 contents of WF were higher (8.9\% compared to $4.6 \%$ for SF) and total starch was also high for 289 WF (76.92\% compared to $50.21 \%$ for SF). The results indicated that intense milling processes 290 have detrimental effect on several properties of the flour. Most of the components such as crude 291 protein, gluten, damaged starch datasets for SF showed highly significant difference $(P<0.01)$ 292 when compared with the WF dataset. This showed that quality of flour was deteriorated while 293 processing and refining.

\section{Benzoyl peroxide concentration}

295 BPO and BA were determined simultaneously using gradient analysis (Table 3). The retention 296 times were observed to be $17.5 \mathrm{~min}$ for BP and $7.8 \mathrm{~min}$ for BA (Fig. 1 \& 2). The maximum 297 absorption of BPO was obtained at $195 \mathrm{~nm}$ and $235 \mathrm{~nm}$, however, a wavelength of $235 \mathrm{~nm}$ was 298 kept as standard for measuring the BP in the samples, considering the possible interference with 299 the food ingredients appearing at $195 \mathrm{~nm}$. The calibration curve had excellent linearity for the range 300 of $0.05-16 \mu \mathrm{g} / \mathrm{g}$ for BPO and $0.2-15 \mu \mathrm{g} / \mathrm{g}$ for BA. The acquisition following isocratic gradient with $30155 \%$ ACN, showed an excellent linearity for BP, however BA was not detected. Therefore, 302 measurements at gradient conditions were kept as standard for the analysis.

303 BPO is a free radical initiator and it causes the oxidation of carotenoids by free radical mechanism. 304 The process (Fig. 3) leads to the formation of benzoic acid (BA) as a by-product (Saiz et al. 2001; 305 Shan et al. 2007; Sumnu \& Sahin 2008). No BA or BP were observed for the Whole Wheat Flour 306 sample (WF) (Fig. 2). In the controlled samples, $30 \mu \mathrm{g} / \mathrm{g}$ of BP was added to the wheat flour 307 samples (grown under standard field conditions) and 99.5\% recovery $(29.5 \mu \mathrm{g} / \mathrm{g}$ ) was observed 308 soon after adding. After $3 \mathrm{~h}$ of bleaching, the amount of BP reduced significantly to $4 \mu \mathrm{g} / \mathrm{g}$ (Fig. 4) 309 that reached to zero after $8 \mathrm{~h}$ of exposure. The contents of BA were observed to be $2.84 \mu \mathrm{g} / \mathrm{g}$ as 310 recovered soon after the addition. This quantity increased to $8.9 \mu \mathrm{g} / \mathrm{g}$ after $3 \mathrm{~h}$ and increased further 311 to $13.5 \mu \mathrm{g} / \mathrm{g}$ after $8 \mathrm{~h}$ of exposure. The contents of BA were determined again after $12 \mathrm{~h}$ though 312 very small increase in quantity was observed $(13.75 \mu \mathrm{g} / \mathrm{g})$, which shows that the process of 313 conversion got stabilized with slight variation. To confirm this, the flour was analyzed again after $31416 \mathrm{~h}$ and quantity of BA didn't change much $(13.77 \mu \mathrm{g} / \mathrm{g})$. Local standards for maximum 315 acceptable quantity have not yet been specified however, international standards $(60 \mu \mathrm{g} / \mathrm{g}$ for BP; $3160-5 \mathrm{mg} / \mathrm{kg}$ for BA as per body weight by JECFA acceptable daily intakes) were considered in the 317 current study. Analysis of WF and SF available commercially for BP and BA showed higher rates 
318 of BA in the SF samples (Table 4). This indicated higher amount of BA intake when SF based

319 products are consumed.

\section{Estimation of daily intake}

321 Estimation of dietary exposure of BA through just wheat flour consumption was estimated (Table

322 5). Since flour is important parameter of people diet, therefore, it was deemed necessary to give 323 the level of exposure through flour only. Rest of the food groups such as noodles and drinks, 324 though unavoidable, also contain certain amount of BA but they were not considered in the current 325 study. As evaluated through questionnaire study most of the considered subjects (72.5) were 326 consuming SF purchased from the flour mills.

327 HPLC was used for quantification of BP in both white and whole wheat flour samples. BA was 328 also determined because BP was decomposed into benzoic acid within limited days (Fig. 4). A 329 research on bleaching agents including BPO and BA by HPLC during bleaching process of wheat 330 flour. The retention time of BP was $17.5 \mathrm{~min}$ and that of BA was $7.6 \mathrm{~min}$. After $30 \mathrm{~h}$ of bleaching 331 BPO concentration was $11 \mathrm{ppm}$. After 3 months its concentration was reduced to $6 \mathrm{ppm}$. These 332 results demonstrated that when benzoyl peroxide added to flour their greater amount was 333 decomposed into benzoic acid within limited days of treatment. The analytical results of present 334 study showed that that retention time of BPO was 17.5 minutes and BA was 7.5 minutes at $235 \mathrm{~nm}$. 335 In WF samples no content of BPO and BA were found. In white flour samples BP content ranges 336 from $6.6-21 \mathrm{mg} / \mathrm{kg}$ and BA content ranges from $13-28 \mathrm{mg} / \mathrm{kg}$.

\section{Discussion:}

338 Whole wheat flour (WF) and Soft Flour (SF) were compared for their properties such as functional 339 properties, emulsifying properties, foaming capacity, gelation capacity, proximate composition 340 and benzoyl peroxide composition. The comparison was developed to aware and understand the 341 choice of flour in daily meals and their potential associated risks.

342 The oil absorption capacity (OAC) of the flour varies with the intrinsic properties such as amino 343 acid composition, protein conformation, hydrophilic-hydrophobic balance of amino acids, steric 344 factors as well as lipid and carbohydrate composition of a flour sample (Mao \& Hua 2012). Results 345 showed that SF samples had more non-polar side chains compared to WF which enhanced the oil 346 binding capacity of SF and reduced its water binding capacity. Higher OAC (188\% compared to 
$347146 \%$ for WF; Table 1) represents that the flour can retain flavor and could have optimum uses in

348 different food products such as bakery items. More hydrophobic sites as in case of SF (OAC

$349>175 \%$ ), as represented through OAC value, are important for bakery items in which fat absorption

350 is desirable (Chandra et al. 2015; Chassagne-Berces et al. 2011). Water Absorption Capacity

351 (WAC) is important since it gives the capacity of a flour to have higher hydration capacity, lower

352

353

354

355

356

357

358

359

360

361

362

363

364

365

366

367

368

369

370

371

372

373

374

375

376

377
WAC $(<123 \%)$ in case of SF and higher in case of WF $(140 \%)$ means that excessive grinding in the flour mills and sieving has resulted in the modification of protein structure. Another factor of higher WAC could be the fibers retaining the water. Reduction of theses fibers in case of SF has reduced its capacity to absorb water (Onipe et al. 2017; Shewry 2009). WAC is an important component since it allows the food to have sufficient water retention and transfer of this water upon consumption. The interaction of protein with water is usually determined through water hydration, holding, water retention and water imbibing. WAC favors another phenomenon called Water Hydration Capacity (WHC). WHC is a physical feature and describes the ability of flour structure to prevent water from being released from a protein structure. During food processing the protein structures are deteriorated which may influence the WHC of wheat as in case of SF. Swelling, another important functional property referred to as spontaneous uptake of water by protein matrix, is indirectly related to WHC. Since SF is lower in WHC therefore its swelling capacity is more ( $>18$ compared to 17.8 in case of WF), which ensures longer life of bakery items. Water retention is very important for protein functionality which determines the cationic, nonionic and anionic polar sites of the protein molecules on the flour surface (Zayas 1997). Lower WHC means that proteins have less water binding capacity or they are "salted out" that takes place when the proteins are precipitated out. (Ramaswamy et al. 2013) showed that the higher water retention is associated with linear form of arabinan compared to its branched form. The branched form of arabinan is unhealthy for consumption, therefore WF should be the choice for consumption instead of SF. The wheat kernel is usually composed of $12-16 \%$ protein, during milling process the protein content and wheat gluten are separated, though gluten is insoluble content of protein. The wheat gluten is further damaged, which may be the reason that in the current results (Table 2) gluten was observed to be higher in concentration compared to protein, since the milling and other processes separated it out.

(Ali et al. 2014) reported that lesser water retention properties are directly related to the damaged starch contents of the wheat. During milling process, the flour obtained comes from the endosperm

PeerJ reviewing PDF | (2019:09:41407:2:2:NEW 19 Feb 2020) 
378 which is rich in starch contents. The physical process of grinding during which the cylinders move 379 closer and closer causes the starch granules to rupture. This results in the damaged starch contents 380 and also has detrimental effect on the protein composition. The higher water retention reflects the 381 absorption of water in the starch granules, which also limit its propagation. In case of WF, the 382 flour is produced through grinding the whole seed (endosperm and periphery) which is rich in 383 pentosan, starch, ash and protein in more or less original form.

384 The emulsifying properties vary inversely with the insoluble protein fractions and polysaccharides 385 (Chove et al. 2001; Haruna et al. 2011). The unfolding of proteins when at interface water/oil 386 determines the Emulsifying Stability (ES) and Emulsifying Activity (EA). ES of protein is related 387 to the ability to minimize the interfacial tension between oil and water when in emulsion. Surface activity is determined through the ability of protein to migrate, deploy, absorb as well as rearrange 389 at interface. The region of the minimum solubility of proteins (isoelectric region) was the region 390 of least soluble and minimum emulsifying capacity. The emulsifying properties vary with the two effects 1) absorption of the protein at oil or water interface results in a substantial decrease in interfacial energy 2) structural, electrostatic and mechanical energy barriers are caused by the 393 interfacial layer that opposes destabilization (Chaparro Acuña et al. 2012; Kumar et al. 2011). This property makes both EA and ES opposite to each other. Higher EA of WF $(>40 \%)$ makes it a 395 preferable choice compared to SF. Akintayo et al. (1999) showed that Foaming Capacity (FC) is associated with the flexibility of protein molecules which reduces the surface tension as well as the globular protein which can hinder surface denaturation, therefore, leading to a low $\mathrm{FC}(<9 \%$ in case of SF). The foaming capacity indicates that proteins have active sites on the flour. Soluble proteins reduce the surface tension when at interface between the fluid surrounding the molecules and air bubbles, which blocks the coalescence. Protein molecules can also be deployed, which interact with each other to give multilayer or film protein which increases the flexibility of air-liquid interface. This results in harder foam due to unbreakable bubbles (Adebowale \& Lawal 2003). Higher FC and Foaming stability (FS) of WF indicates that protein structures are not denatured yet and they still carry the capacity; however, in case of SF they seem to have lost their arrangement due to which reduced 406 foaming properties has been observed.

407 Protein gelation is very important in several vegetables and other food items. The effective 408 overlapping of the functional groups between adjacent protein moieties is very important for the 
409 gel network formation. Higher gelation capacity (Gelatinization temperature) for WF indicates that 410 this may not be a good choice in bakery items.

411 The flour at the beginning of the process comes from the endosperm, which is rich in starch and 412 as it reaches the end of grinding, flour comes from periphery which is rich in ash, pentosan and 413 protein. During the milling process, the seeds pass through heavy grinders to attain fine powdered 414 flour. This flour is further sieved and final product, obtained after series of sieving and treatment 415 with BP, is packed and sold as commercial white flour used for bakery items. Most of the 416 components such as crude protein, gluten, damaged starch datasets showed highly significant 417 difference $(P<0.001)$ with the WF dataset. This shows that quality of SF was deteriorated during 418 processing and refining.

419 Flour mills consume benzoyle peroxide (BP) to improve the appearance and white colour of flour. $420 \mathrm{BP}$ is a free radical initiator and therefore, it causes the oxidation of carotenoids by free radical 421 mechanism. The process (Fig. 3) leads to the formation of benzoic acid (BA) as a by-product (Saiz 422 et al. 2001; Shan et al. 2007; Sumnu \& Sahin 2008). (Onishi et al. 2004a) reported that Chigasaki 423 Health Centre in Kanagawa Prefecture in Japan observed about 60-100 $\mu \mathrm{g} / \mathrm{g}$ of BA in December 424 1999, which was found to be due to BP introduced in the food items; therefore BP was being 425 decomposed into BA. Current study suggested that not all BP was converted into BA, therefore 426 traces are still left in the sample which was in compliance with the findings of the previous studies 427 (Onishi et al. 2004a; Ponhong et al. 2015). Further analyses of SF indicated that all samples had 428 traces of BP and excessive amount of BA in them. Study by (Ponhong et al. 2015) indicated that 429 not all BP could get converted to BA and slight amount of BA is also introduced during the 430 bleaching process that helps in the initiation of conversion process. The Joint FAO/WHO Expert 431 Committee on Food Additives (JECFA) has approved the quantity of BP allowable to be about 0$43240 \mathrm{mg} / \mathrm{kg}$ which has also been approved by (Organization 2001) considering the requirement of 433 whitening of flour. However, increased temperature during baking also speeds up the processes of 434 metabolism of BP to it's by products (and BA in particular). The maximum allowable level for $435 \mathrm{BA}$ is $150 \mathrm{mg} / \mathrm{L}$ according to European community food safety regulations $(\mathrm{EC}, 1995)$, which 436 means daily intake of $55.8 \mathrm{mg}$ of BA per person or $0.8 \mathrm{mg} / \mathrm{kg}$ body weight assuming $70 \mathrm{~kg}$ of 437 weight is allowed (Solomon et al. 2005). According to JECFA acceptable daily intake was 0-5 $438 \mathrm{mg} / \mathrm{kg}$ for BA and benzoate. Intake of benzoic acid in sensitive persons, lower than $5 \mathrm{mg} / \mathrm{kg}$ of 439 body weight per day has been observed to cause non-immunological contact reaction. A few 
440 studies have reported strong allergic reactions such as urticarial, pruritus and rhinitis to benzoic 441 acid and benzoate exposure. According to current study, Table 5, SF consumers gain 44.3 $442 \mathrm{mg} / \mathrm{kg} / \mathrm{bw}$ of BA per day which is above maximum allowable intake $(5 \mathrm{mg} / \mathrm{kg} / \mathrm{bw})$ compared to 443 those who consume WF.

444 Wheat flour is an unavoidable commodity. This shows that white SF as produced out of milling 445 process are contributors of excessive amount of toxic benzoic acid (BA) in the consumers' body. 446 Results of current study indicated very high amount of BA entering in human body upon 447 consumption of SF. In China standard limit of BPO is not exceed $60 \mathrm{mg} / \mathrm{Kg}$; the maximum content 448 of BP in wheat flour is $80 \mathrm{mg} / \mathrm{Kg}$ in the US, in Japan $300 \mathrm{mg} / \mathrm{Kg}$, and also $50 \mathrm{mg} / \mathrm{Kg}$ in United 449 Kingdom. In China, permissible amount of BPO are $0.045,0.050 .06 \mathrm{~g} / \mathrm{kg}$ according to standards 450 of food additives regulation (Wei et al. 2006). According to Japanese regulations allow the use of 451 diluted BPO $(19-22 \% \mathrm{w} / \mathrm{w})$ in wheat flour which is lesser than $0.30 \mathrm{~g} / \mathrm{kg}$. In France, the use of BP 452 is strictly banned. In UK and USA the permitted level BPO are $0.05 \mathrm{~g} / \mathrm{kg}, 0.045 \mathrm{~g} / \mathrm{kg}$ respectively 453 (Saiz et al. 2001). These standard limits demonstrated that the concentration of BP in SF was 454 within permissible limit, however when this value was calculated on the basis of Avg. Daily Intake 455 (ADI) and Estimated Daily Intake (EDI) (Table 5) it was observed that influx of BA in the body 456 of consumers is very high, which is $44.3 \mathrm{mg} / \mathrm{kg} /$ day compared to allowable level of $0-5 \mathrm{mg} / \mathrm{kg} / \mathrm{day}$. 457 Current study showed an EDI of $78.3 \mathrm{~g}$ /day if a person consumes Results revealed that regular 458 consumption of SF has profound effect on human health, therefore WF should be a preferable 459 choice instead.

460

461

462

463

464

465

466

467

468

\section{Conclusions}

Wheat flour is one of the most important ingredients of food being consumed most frequently. To improve the baking quality, SF is often used instead of WF. Increased demands of fine texture and bleached colour has led flour millers to add enhanced concentration of BPO and extensive milling along with sieving. Extensive milling and increased BPO reduce the nutritive value of SF and enrich it with the toxicant such as BA (as degradation product of BPO). Among various parameters of flour quality, protein and ash content in WF sample was more than SF samples. Therefore, there is need to improve wheat flour quality being sold in the market by limiting the rate of BPO added as bleaching agent as well milling process should be improved. HPLC analyses effectively 
469

470

471

472

473

474

475

476

477

478

479

480

481

482

483

484

485

486

487

488

489

490

491

492

493

494

495

496

497

498

499

500

501

502

503

504

505

506

507

508

509

510

511

512

513

demonstrated the dissociation of BPO to BA, which means that BA in SF was due to BPO added as bleaching agent.

\section{References}

Adebowale K, and Lawal O. 2003. Foaming, gelation and electrophoretic characteristics of mucuna bean (Mucuna pruriens) protein concentrates. Food Chemistry 83:237246.

Akintayo E, Oshodi A, and Esuoso K. 1999. Effects of $\mathrm{NaCl}$, ionic strength and $\mathrm{pH}$ on the foaming and gelation of pigeon pea (Cajanus cajan) protein concentrates. Food Chemistry 66:51-56.

Ali R, Khan MS, Sayeed SA, Ahmed R, Saeed SMG, and Mobin L. 2014. Relationship of damaged starch with some physicochemical parameters in assessment of wheat flour quality. Pakistan Journal of Botany 46:2217-2225.

Beuchat LR. 1977. Functional and electrophoretic characteristics of succinylated peanut flour protein. Journal of agricultural and food chemistry 25:258-261.

Casanova F, Nakamura A, Masuda H, Lima L, and Fialho E. 2008. Functionality of phosphorylated vicilin exposed to chemical and physical agents. Food Chemistry 107:1138-1143.

Chandra S, Singh S, and Kumari D. 2015. Evaluation of functional properties of composite flours and sensorial attributes of composite flour biscuits. Journal of food science and technology 52:3681-3688.

Chaparro Acuña SP, Gil González JH, and Aristizábal Torres ID. 2012. Physicochemical characteristics and functional properties of vitabosa (mucuna deeringiana) and soybean (glycine max). Food Science and Technology 32:98-105.

Chassagne-Berces S, Leitner M, Melado A, Barreiro P, Correa EC, Blank I, Gumy J-C, and Chanvrier H. 2011. Effect of fibers and whole grain content on quality attributes of extruded cereals. Procedia Food Science 1:17-23.

Chove BE, Grandison AS, and Lewis MJ. 2001. Emulsifying properties of soy protein isolate fractions obtained by isoelectric precipitation. Journal of the Science of Food and Agriculture 81:759-763.

Coffmann C, and Garciaj V. 1977. Functional properties and amino acid content of a protein isolate from mung bean flour. International Journal of Food Science \& Technology 12:473-484.

Gaddipati N, Volpe F, and Anthony G. 1983. Quantitative determination of benzoyl peroxide by high-performance liquid chromatography and comparison to the iodometric method. Journal of pharmaceutical sciences 72:1398-1400.

Haruna M, Udobi C, and Ndife J. 2011. Effect of added brewers dry grain on the physicochemical, microbial and sensory quality of wheat bread. American Journal of Food and Nutrition 1:39-43.

Isabelle L, and Andre L. 2006. Quantitative prediction of microbial behaviour during food processing using an integrated modelling approach: a review. International Journal of Refrigeration 29:968-984.

Jehu-Appiah C, Aryeetey G, Agyepong I, Spaan E, and Baltussen R. 2011. Household perceptions and their implications for enrolment in the National Health Insurance Scheme in Ghana. Health Policy and Planning 27:222-233.

Peer] reviewing PDF | (2019:09:41407:2:2:NEW 19 Feb 2020) 
514

515

516

517

518

519

520

521

522

523

524

525

526

527

528

529

530

531

532

533

534

535

536

537

538

539

540

541

542

543

544

545

546

547

548

549

550

551

552

553

554

555

556

557

558

559

560

561

562

563

564

Kumar P, Yadava R, Gollen B, Kumar S, Verma RK, and Yadav S. 2011. Nutritional contents and medicinal properties of wheat: a review. Life Sci Med Res 22:1-10.

Liu RH. 2007. Whole grain phytochemicals and health. Journal of Cereal Science 46:207219.

Liu Y, Zhao J, Li Z, Mu C, Ma W, Hu H, Jiang K, Lin H, Ade H, and Yan H. 2014. Aggregation and morphology control enables multiple cases of high-efficiency polymer solar cells. Nature communications 5:5293.

Mao X, and Hua Y. 2012. Composition, structure and functional properties of protein concentrates and isolates produced from walnut (Juglans regia L.). International journal of molecular sciences 13:1561-1581.

Mellado-Ortega E, and Hornero-Méndez D. 2017. Effect of long-term storage on the free and esterified carotenoids in durum wheat (Triticum turgidum conv. durum) and tritordeum ( $\times$ Tritordeum Ascherson et Graebner) grains. Food Research International 99:877-890.

Neto VQ, Narain N, Silva J, and Bora P. 2001. Functional properties of raw and heat processed cashew nut (Anacardium occidentale, L.) kernel protein isolates. Food/Nahrung 45:258-262.

Onipe OO, Beswa D, and Jideani AIO. 2017. Effect of size reduction on colour, hydration and rheological properties of wheat bran. Food Science and Technology (Campinas):0-0.

Onishi H, Araki T, Shirato H, Nagata Y, Hiraoka M, Gomi K, Yamashita T, Niibe Y, Karasawa K, and Hayakawa K. 2004a. Stereotactic hypofractionated high-dose irradiation for stage I nonsmall cell lung carcinoma. Cancer 101:1623-1631.

Onishi H, Araki T, Shirato H, Nagata Y, Hiraoka M, Gomi K, Yamashita T, Niibe Y, Karasawa K, and Hayakawa K. 2004b. Stereotactic hypofractionated high-dose irradiation for stage I nonsmall cell lung carcinoma: clinical outcomes in 245 subjects in a Japanese multiinstitutional study. Cancer 101:1623-1631.

Organization WH. 2001. The World Health Report 2001: Mental health: new understanding, new hope: World Health Organization.

Ponhong K, Teshima N, Grudpan K, Vichapong J, Motomizu S, and Sakai T. 2015. Successive determination of urinary bilirubin and creatinine employing simultaneous injection effective mixing flow analysis. Talanta 133:71-76.

Ramaswamy UR, Kabel MA, Schols HA, and Gruppen H. 2013. Structural features and water holding capacities of pressed potato fibre polysaccharides. Carbohydrate polymers 93:589-596.

Saiz A, Manrique G, and Fritz R. 2001. Determination of benzoyl peroxide and benzoic acid levels by HPLC during wheat flour bleaching process. Journal of agricultural and food chemistry 49:98-102.

Shan D, Shi Q, Zhu D, and Xue H. 2007. Inhibitive detection of benzoic acid using a novel phenols biosensor based on polyaniline-polyacrylonitrile composite matrix. Talanta 72:1767-1772.

Shewry P. 2009. The HEALTHGRAIN programme opens new opportunities for improving wheat for nutrition and health. Nutrition Bulletin 34:225-231.

Solomon K, Anadon A, Cerdeira A, Marshall J, and Sanin L. 2005. Informe preparado para la Comisión Interamericana para el control y el abuso de drogas (CICAD).

Sumnu SG, and Sahin S. 2008. Food engineering aspects of baking sweet goods: CRC Press.

Theerarattananoon K, Xu F, Wilson J, Ballard R, Mckinney L, Staggenborg S, Vadlani P, Pei Z, and Wang D. 2011. Physical properties of pellets made from sorghum stalk, corn stover, wheat straw, and big bluestem. Industrial Crops and Products 33:325332.

Peer) reviewing PDF | (2019:09:41407:2:2:NEW 19 Feb 2020) 
565 Wei L, Zhujun Z, and Liu Y. 2006. Chemiluminescence microfluidic chip fabricated in

566

PMMA for determination of benzoyl peroxide in flour. Food Chemistry 95:693-698.

567 Zayas JF. 1997. Solubility of proteins. Functionality of proteins in food: Springer, 6-75. 
Figure 1

HPLC chromatogram of BPO (17.56 min) and BA (7.018 $\mathrm{min})$ in WF when induced with $30 \mu \mathrm{g} / \mathrm{g}$ of BP. 

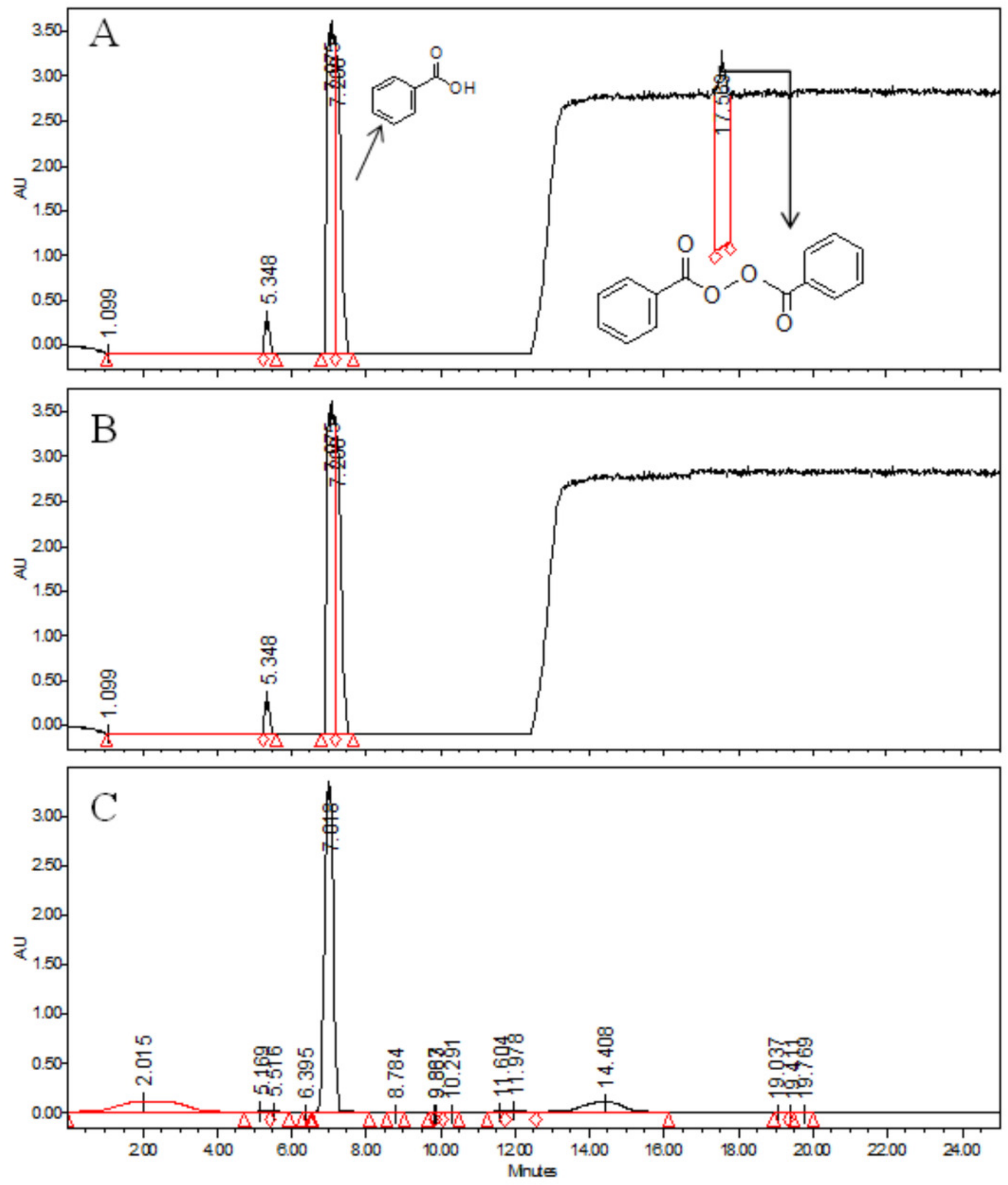
Figure 2

HPLC chromatograms for BPO and BA

HPLC chromatograms for BPO and BA in A) commercial soft flour (SF1) B) whole flour (WF) without any addition of preservatives.
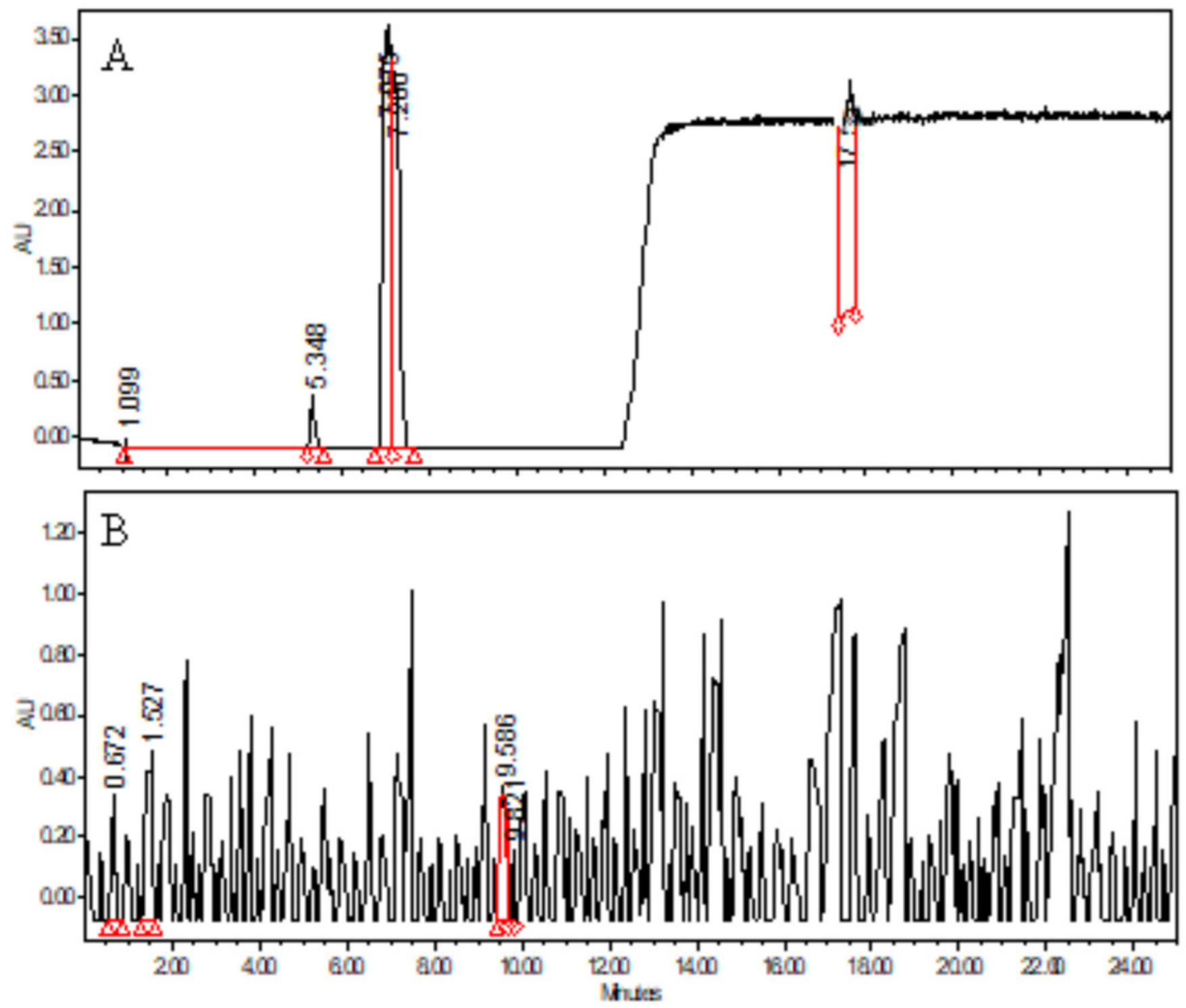
Figure 3

Possible pathway for the degradation of benzoyl peroxide (BPO) to benzoic acid (BA) as observed through current research.

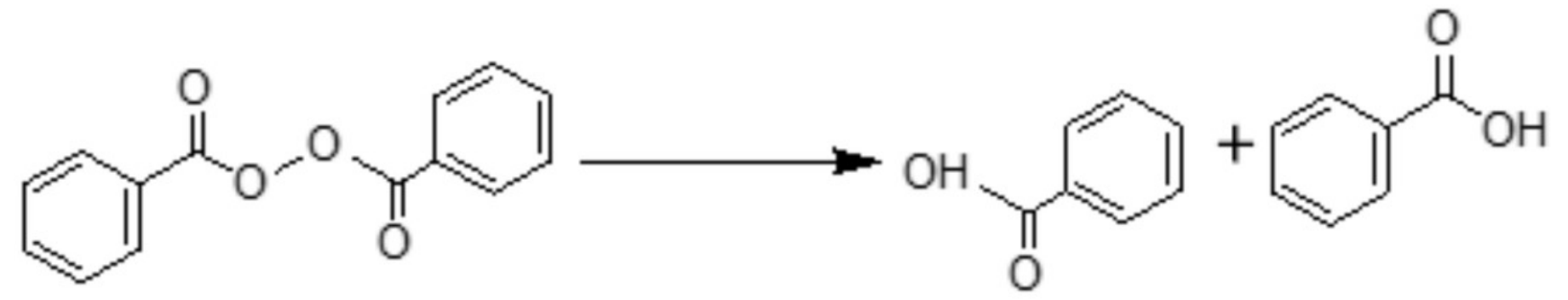


Figure 4

Rate of conversion of benzoyl peroxide (BP) to benzoic acid (BA) in flour at varied time intervals.

Rate of conversion of benzoyl peroxide (BP) to benzoic acid (BA) in flour at varied time intervals. About $50 \mathrm{~g}$ of flour was amended with $30 \mu \mathrm{g} / \mathrm{g}$ of BPO as bleaching agent. Rate of dissociation was observed over a period of $16 \mathrm{~h}$.

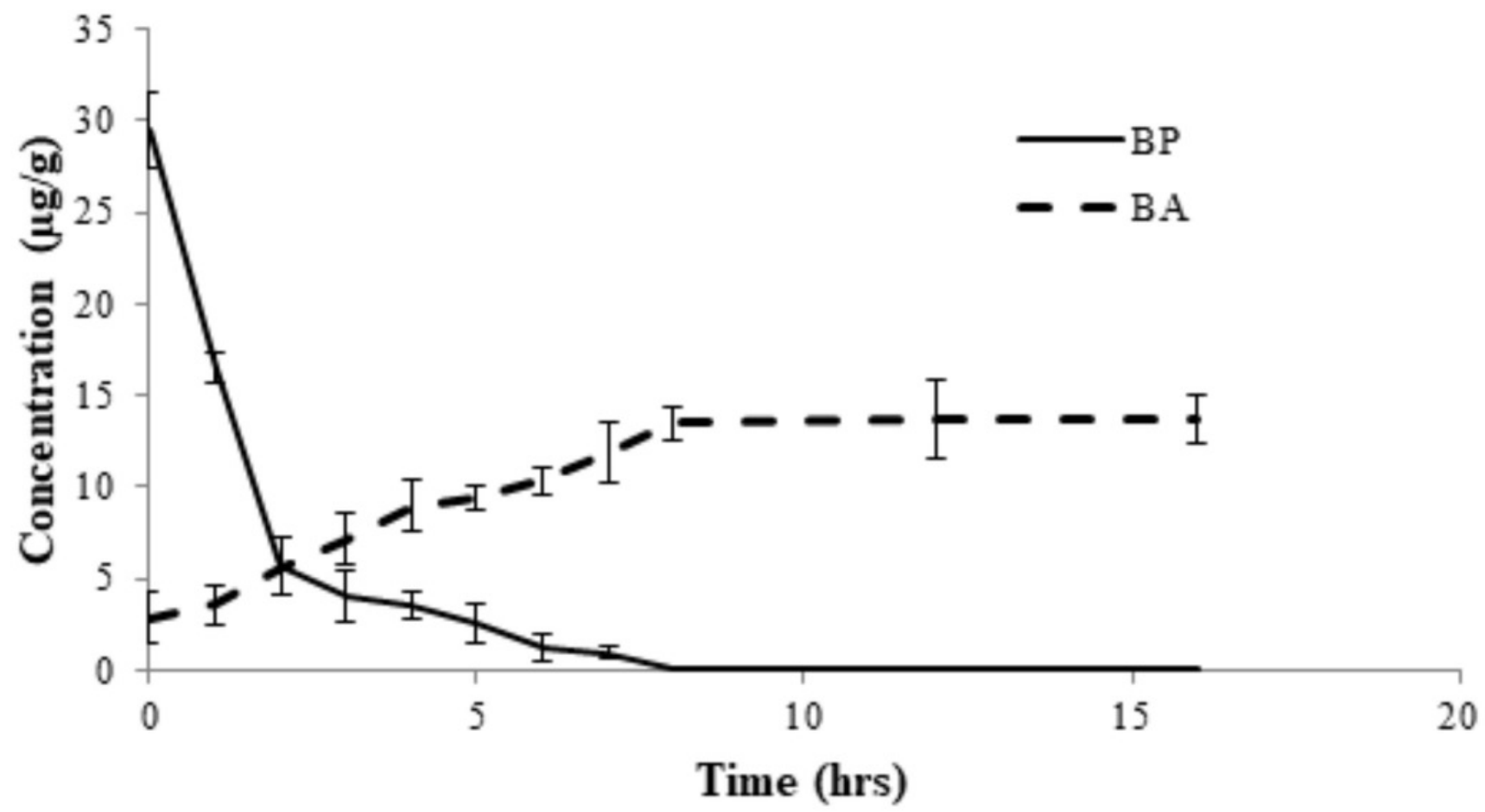




\section{Table $\mathbf{1}$ (on next page)}

Functional Properties of the whole wheat flour (WF) and soft flour (SF) samples $(* P<0.05 ; * * P<0.01$; significant difference as calculated through ANOVA).

Notes: *SC=swelling capacity; $\mathrm{WAC}=$ water absorption capacity; $\mathrm{OAC}=$ oil absorption capacity; $E A=$ emulsifying activity; $E S=$ =mulsifying stability; $F C=$ foaming capacity; $F S=$ foaming stability; $\mathrm{GnT}=$ gelatinization temp.; $\mathrm{LGC}=$ least gelatinization concentration; $\mathrm{BD}=$ bulk density 


\begin{tabular}{|c|c|c|c|c|c|c|c|c|c|c|}
\hline Samples & $\begin{array}{l}\text { SC at } \\
95^{\circ} \mathrm{C} \\
(\mathrm{g} / \mathrm{mL}) \\
\text { Mean } \pm S \\
\mathrm{D}\end{array}$ & $\begin{array}{l}\text { WAC } \\
(\mathrm{g} / \mathbf{1 0 0 m} \\
\mathrm{L}) \\
\text { Mean } \pm \\
\text { SD }\end{array}$ & $\begin{array}{l}\text { OAC } \\
(g / 100 g) \\
\text { Mean } \pm \\
\text { SD }\end{array}$ & $\begin{array}{l}\text { EA }(\%) \\
\operatorname{Mean} \pm S \\
\text { D }\end{array}$ & $\begin{array}{l}\text { ES } \\
(\%) \\
\text { Mean } \pm \\
\text { SD }\end{array}$ & $\begin{array}{l}\text { FC } \\
(\%) \\
\text { Mean } \\
\pm \text { SD }\end{array}$ & $\begin{array}{l}\text { FS } \\
(\%) \\
\text { Mean } \\
\pm \text { SD }\end{array}$ & $\begin{array}{l}\text { GnT } \\
\left({ }^{\circ} \mathrm{C}\right) \\
\text { Mean } \\
\pm \text { SD }\end{array}$ & $\begin{array}{l}\text { LGC } \\
(\%) \\
\text { Mean } \\
\pm \text { SD }\end{array}$ & $\begin{array}{l}\text { BD }(\rho) \\
\text { Mean } \pm \text { SD }\end{array}$ \\
\hline WF & $17.8 \pm 1.2$ & $140 \pm 5.77$ & $146 \pm 9.33$ & $\begin{array}{l}43.7 \pm 2.6 \\
1\end{array}$ & $\begin{array}{l}38.4 \pm 5 \\
77\end{array}$ & $\begin{array}{l}12.9_{ \pm} \\
1.02\end{array}$ & $\begin{array}{l}1.94 \pm \\
0.07\end{array}$ & $\begin{array}{l}59.21 \pm \\
1.39\end{array}$ & $8 \pm 1.65$ & $0.76 \pm 0.048$ \\
\hline SF1 & $\begin{array}{l}19.4 \pm 0.9 \\
8\end{array}$ & $121 \pm 4.04$ & $181 \pm 8.75$ & $\begin{array}{l}37.84 \pm 3 \\
47\end{array}$ & $\begin{array}{l}44.6 \pm 7 . \\
54\end{array}$ & $\begin{array}{l}8.97 \pm \\
1.22 * *\end{array}$ & $\begin{array}{l}0.77 \pm \\
0.065\end{array}$ & $\begin{array}{l}41.21 \pm \\
1.66^{*}\end{array}$ & $6 \pm 0.98^{*}$ & $0.23 \pm 0.06$ \\
\hline SF2 & $\begin{array}{l}18.8 \pm 0.9 \\
7\end{array}$ & $123 \pm 8.93$ & $175 \pm 7.63$ & $\begin{array}{l}36.44 \pm 7 \\
12\end{array}$ & $\begin{array}{l}45.4 \pm 8 \\
75\end{array}$ & $\begin{array}{l}8.66 \pm \\
1.08 * *\end{array}$ & $\begin{array}{l}0.84 \pm \\
0.078\end{array}$ & $\begin{array}{l}38.7 \pm 1 \\
.86^{*}\end{array}$ & $\begin{array}{l}4 \pm 0.87 * \\
*\end{array}$ & $0.24 \pm 0.056$ \\
\hline SF3 & $\begin{array}{l}19.6 \pm 0.8 \\
1\end{array}$ & $120 \pm 2.36$ & $184 \pm 8.55$ & $\begin{array}{l}38.45 \pm 3 \\
22\end{array}$ & $\begin{array}{l}43.5 \pm 8 . \\
41\end{array}$ & $\begin{array}{l}8.71 \pm \\
1.76^{* *}\end{array}$ & $\begin{array}{l}0.76 \pm \\
0.065\end{array}$ & $\begin{array}{l}37.74 \pm \\
2.06^{*}\end{array}$ & $\begin{array}{l}4 \pm 0.65 * \\
*\end{array}$ & $0.21 \pm 0.081$ \\
\hline SF4 & $\begin{array}{l}19.7 \pm 1.7 \\
2\end{array}$ & $118 \pm 3.45$ & $188 \pm 9.34$ & $\begin{array}{l}36.7 \pm 4.2 \\
1\end{array}$ & $\begin{array}{l}42.9 \pm 7 . \\
66\end{array}$ & $\begin{array}{l}8.34 \pm \\
0.51 * *\end{array}$ & $\begin{array}{l}0.74 \pm \\
0.045\end{array}$ & $\begin{array}{l}38.45 \pm \\
2.76^{*}\end{array}$ & $\begin{array}{l}4 \pm 0.77 * \\
*\end{array}$ & $0.26 \pm 0.056$ \\
\hline
\end{tabular}




\section{Table 2 (on next page)}

Proximate composition of whole wheat flour (WF) and soft flour (SF) samples ( $* P<0.05$; $* * P<0.01$; significant difference as calculated through ANOVA). 


\begin{tabular}{|c|c|c|c|c|c|c|c|c|c|c|}
\hline Samples & $\begin{array}{l}\text { Moisture } \\
(\%) \\
\text { Mean } \pm \text { SD }\end{array}$ & $\begin{array}{l}\text { Ash } \\
(\%) \\
\text { Mean } \\
\pm \text { SD }\end{array}$ & $\begin{array}{l}\text { Crude } \\
\text { fibre } \\
(\%) \\
\text { Mean } \pm S \\
\text { D }\end{array}$ & $\begin{array}{l}\text { Fat } \\
(\%) \\
\text { Mean } \\
\pm \text { SD }\end{array}$ & $\begin{array}{l}\text { Crude } \\
\text { Protein } \\
(\%) \\
\text { Mean } \pm S \\
\text { D }\end{array}$ & $\begin{array}{l}\text { Gluten } \\
(\%) \\
\text { Mean } \pm \\
\text { SD }\end{array}$ & $\begin{array}{l}\text { Starch } \\
(\%) \\
\text { Mean } \pm S \\
\text { D }\end{array}$ & $\begin{array}{l}\text { Sugar } \\
(\%) \\
\text { Mean } \pm \\
\text { SD }\end{array}$ & $\begin{array}{l}\text { Damaged } \\
\text { starch } \\
(\%) \text { Mean } \\
\pm \text { SD }\end{array}$ & $\begin{array}{l}\text { Pentosan } \\
(\%) \\
\text { Mean } \pm \text { SD }\end{array}$ \\
\hline WF & $8.64 \pm 0.054$ & $\begin{array}{l}1.6 \pm 0 . \\
08\end{array}$ & $\begin{array}{l}1.44 \pm 0.0 \\
76\end{array}$ & $\begin{array}{l}2.29_{ \pm} \\
0.15 \\
\end{array}$ & $8.9 \pm 1.24$ & $\begin{array}{l}14.4 \pm 0.7 \\
8\end{array}$ & $\begin{array}{l}76.92 \pm 4.3 \\
2\end{array}$ & $\begin{array}{l}16.92 \pm 1 . \\
07\end{array}$ & $45.84 \pm 5.42$ & $1.6 \pm 0.07$ \\
\hline SF1 & $4.25 \pm 1.23^{*}$ & $\begin{array}{l}0.54 \pm \\
0.064\end{array}$ & $\begin{array}{l}0.34 \pm 0.0 \\
76^{*}\end{array}$ & $\begin{array}{l}1.54 \pm \\
0.98\end{array}$ & $\begin{array}{l}4.65 \pm 0.86 \\
* *\end{array}$ & $7 \pm 1.23 * *$ & $\begin{array}{l}50.26 \pm 1.8 \\
6^{* *}\end{array}$ & $\begin{array}{l}23.41 \pm 3 . \\
74\end{array}$ & $\begin{array}{l}88.36 \pm 4.32 * \\
*\end{array}$ & $0.25 \pm 0.054$ \\
\hline SF2 & $4.22 \pm 0.83 *$ & $\begin{array}{l}0.55 \pm \\
0.043\end{array}$ & $\begin{array}{l}0.34 \pm 0.0 \\
7 *\end{array}$ & $\begin{array}{l}1.32 \pm \\
0.05\end{array}$ & $\begin{array}{l}4.32 \pm 0.85 \\
* *\end{array}$ & $\begin{array}{l}7.5 \pm 2.21 \\
* *\end{array}$ & $\begin{array}{l}50.4 \pm 2.77 \\
* *\end{array}$ & $\begin{array}{l}23.15 \pm 8 . \\
75\end{array}$ & $\begin{array}{l}87.22 \pm 2.05 * \\
*\end{array}$ & $0.23 \pm 0.055$ \\
\hline SF3 & $3.84 \pm 0.67 * *$ & $\begin{array}{l}0.45 \pm \\
0.081\end{array}$ & $\begin{array}{l}0.32 \pm 0.0 \\
5^{*}\end{array}$ & $\begin{array}{l}1.12 \pm \\
0.063\end{array}$ & $\begin{array}{l}4.15 \pm 1.65 \\
* *\end{array}$ & $6 \pm 1.22 * *$ & $\begin{array}{l}50.21 \pm 1.2 \\
4 * *\end{array}$ & $\begin{array}{l}23.4 \pm 6.3 \\
4\end{array}$ & $82.3 \pm 1.24 * *$ & $0.24 \pm 0.07$ \\
\hline SF4 & $3.9 \pm 0.17^{* *}$ & $\begin{array}{l}0.34 \pm \\
0.049\end{array}$ & $\begin{array}{l}0.33 \pm 0.0 \\
74^{*}\end{array}$ & $\begin{array}{l}1.12 \pm \\
0.048\end{array}$ & $\begin{array}{l}4.12 \pm 0.08 \\
* *\end{array}$ & $\begin{array}{l}6.5 \pm 1.07 \\
* *\end{array}$ & $\begin{array}{l}50.21 \pm 4.3 \\
2 * *\end{array}$ & $\begin{array}{l}23.25 \pm 3 . \\
45\end{array}$ & $\begin{array}{l}85.62 \pm 2.23 * \\
*\end{array}$ & $0.26 \pm 0.05$ \\
\hline
\end{tabular}




\section{Table 3(on next page)}

Recoveries of Benzoyl peroxide (BP) and Benzoic acid (BA) from the flour. 


\begin{tabular}{|c|l|l|l|}
\hline \multirow{2}{*}{ Components } & \multirow{2}{*}{$\begin{array}{c}\text { Added amount } \\
(\boldsymbol{\mu g} / \mathbf{g})\end{array}$} & $\begin{array}{l}\text { Recovery (\%) } \\
\text { Mean } \pm \mathbf{S D}\end{array}$ & $\begin{array}{l}\text { Isocratic } \\
\text { Mean } \pm \text { SD }\end{array}$ \\
\hline \multirow{3}{*}{ Benzoyl peroxide } & 7 & $98.1 \pm 0.55$ & $99.2 \pm 0.41$ \\
\cline { 2 - 4 } & 30 & $99.5_{ \pm 0.61}$ & $99.3 \pm 0.55$ \\
\cline { 2 - 4 } & 60 & $96 \pm 0.25$ & $99.3 \pm 0.21$ \\
\hline \multirow{2}{*}{ Benzoic acid } & 5 & $91.3 \pm 0.44$ & - \\
\cline { 2 - 4 } & 10 & $91.3 \pm 0.31$ & - \\
\hline
\end{tabular}


Table 4 (on next page)

Concentrations of BP and BA in different flour samples.

WF $=$ Whole wheat flour; $\mathrm{SF}=$ Soft flour 


\begin{tabular}{|l|c|c|}
\hline \multirow{2}{*}{ Samples } & \multicolumn{2}{|c|}{ Contents $(\boldsymbol{\mu g} / \mathbf{g})$} \\
\cline { 2 - 3 } & $\begin{array}{c}\text { BP } \\
\text { Mean } \pm \text { SD }\end{array}$ & $\begin{array}{c}\text { BA } \\
\text { Mean } \pm \text { SD }\end{array}$ \\
\hline WF & 0 & 0 \\
\hline SF1 & $2.45 \pm 1.1$ & $68.11_{ \pm 14.1}$ \\
\hline SF2 & $3.41_{ \pm 1.02}$ & $71.4_{ \pm 12.31}$ \\
\hline SF3 & $2.54 \pm 0.94$ & $71.51_{ \pm 15.84}$ \\
\hline SF4 & $5.77_{ \pm 0.33}$ & $72.55_{ \pm 15.33}$ \\
\hline
\end{tabular}




\section{Table 5 (on next page)}

Estimated intake of BA on the basis of intake of flour by consumers.

Allowable EDI for $\mathrm{BA}=0-5 \mathrm{mg} / \mathrm{kg} / \mathrm{bw}$ 


\begin{tabular}{|l|l|l|l|}
\hline Food group & Consumer (\%) & $\begin{array}{c}\text { Avg. Daily intake of } \\
\text { flour (g/day) } \\
\text { Mean } \pm \text { SD }\end{array}$ & $\begin{array}{c}\text { Estimated daily intake of } \\
\text { BA (mg/kg/bw) } \\
\text { Mean } \pm \text { SD }\end{array}$ \\
\hline SF & 72.5 & $78.3 \pm 2.3$ & $44.3 \pm 1.36$ \\
\hline WF & 10.5 & $72.1 \pm 3.3$ & $1.34 \pm 1.45$ \\
\hline Alternate & 17 & $68.3 \pm 1.23$ & - \\
\hline
\end{tabular}

1 